\title{
The Role of Branding in SMEs: Different Perspective on the Market
}

\author{
Franc Vidic, Jaka Vadnjal \\ GEA College, Faculty of entrepreneurship, Piran, Slovenia
}

\begin{abstract}
This paper examines the role of branding among Slovenian small and medium sized enterprises (SMEs) and attitude of entrepreneurs to branding strategy. The term "branding" is usually dominated by big global businesses which operate on world mostly consumer markets and build their competitive strategies on powerful branding. Also in academic research literature and textbook, efficient brands are frequently mentioned, particularly in connection with large global companies. However, also SME nurture their own specific approach to branding development although these processes may not be on a conscious level of thinking. Many SMEs are facing dilemmas connected with investing money, time, and energy to change the established practice, and to undertake a strategic approach to brand management. Based on extensive literature survey and researchers' own experience, a questionnaire was developed to measure the branding development attitude of SMEs. A random sample of companies with at least five employees with the purpose of eliminate micro businesses for which the issue of branding may not be that relevant enabled a level of significance which allows generalization of results. By using descriptive statistics and cluster analysis, we were able to determine the use and position of brand management within the strategic orientation context of researched companies. An important result of the study is the classification system of SMEs, with regard to their market position and future perspective. The participating companies were categorized into the following four groups (clusters): (1) ignorant, (2) users, (3) low-cost producers, and (4) differentiation producers. The ignorant are predominantly micro businesses serving only local markets with no ambition for any growth. The users are businesses of early growth which may not be entirely aware of the potential of branding which is consistent to their generic strategy which may not be refined yet. The low-cost producers and differentiation producers already utilize branding to backup their chosen core strategic orientation. While the first two groups tend to be more passive, the last two groups pursue more proactive strategic orientation. The main finding of the paper is therefore an empirical confirmation of the theoretical stand that branding should not be a sole-standing business function but merely embedded into the core generic strategy which a company is following.
\end{abstract}

Keywords: small and medium enterprises (SMEs), branding, strategies, Slovenia

\section{Introduction}

Branding in SMEs has been a relatively new subject in the business research. Although there has been a lot of contribution on this topic, both in text-books and academic research literature, most theories and case studies

Franc Vidic, Ph.D., GEA College, Faculty of entrepreneurship.

Jaka Vadnjal, Ph.D., GEA College, Faculty of entrepreneurship.

Correspondence concerning this article should be addressed to Franc Vidic, Ph.D., Kidričevo nabrežje 2, 6330 Piran, Slovenia. E-mail: franc.vidic@gea-college.si. 
base on well-known global brands (i.e., Coca Cola, Nike, etc.). Research among SMEs has been so far limited to large corporations, the reason for that has probably been in the fact that SMEs because of their financial and human limitations of resources usually do not run a formalized process which would deal with branding. They deal with brands on their own specific way. Thus, alike several other business functions in SMEs, also the function of branding is designed spontaneously and simultaneously depend of growth, life-cycle development, and organizational culture. Start-ups which are based on powerful brands or, to put it differently, when creation, development, and exploitation of brand are actually a business idea, are extremely rare.

Thus, the main motivation of the research for this particular article explores strategic orientation and activities to branding among SMEs. They have been labeled: ignorant companies, users, low-cost suppliers, and differentiated suppliers. The first two groups are formed on the basis of different levels of complexity of otherwise very simplistic performed branding practice which is mostly utilized on local markets where those businesses predominantly operate. The last two groups are positioned in accordance with defined generic strategy of a particular company. Generally, it has been concluded that the awareness and the role of branding in small and medium companies in Slovenia are moderately low.

\section{Literature Review}

Competition in the global economy has been becoming fiercer every day by day. Small and medium sized businesses (SMEs) contribute significantly to a country's gross domestic product, national job creation, and export performance (Culkin \& Smith, 2000). In order to survive, grow, and compete in this more and more competitive climate, entrepreneurs of SMEs need to study market conditions and implement effective strategies (Slater \& Narver, 2000). SMEs tend to be more entrepreneurial, flexible, and innovative, which makes them more adaptive at serving specialist or niche markets and remaining and even increasing their responsiveness to customer needs (Goldberg, Coben, \& Fiegenbaum, 2003). SMEs have more opportunities to get close to customers and obtain valuable feedback, which can then be utilized to provide clients with a customized and high value-added service (Gilmore, Carson, \& Grant, 1999).

Among all the competitive tools available to SMEs, we argue that branding should be close if not on the top of the list (Anarnkaporn, 2007). Brands often provide primary elements of differentiation between competitive offerings and as such, can be critical success factors of companies (Mowle \& Merrilees, 2005). It provides a name or symbol that gives product credibility and helps consumer to identify the product (Gillespie, Jeanett, \& Hennesy, 2007), it gives the product meaning and defines its identity in both time and space (Kapferer, 1997). But branding, especially corporate branding is often a radically new concept for people in SMEs (Inskip, 2004).

SME's organizations should develop their brands for smaller market share and higher levels of loyalty (McAlester, 2006; Kohli, Harich, \& Leuthesser, 2005). Kahn, Kalwani, and Morrison (1988) noted that small segments of consumers develop needs, which differ from those of the general uses of the product class, thus providing opportunities for speciality brands. SMEs should know their customers in a time horizon offering highly customized and personally used service (Chen, 2001). Brands add value and differentiation opportunities from competitors (Grant, 2000; Ratnatunga \& Ewing, 2009) and its integrity and competence resulting from the creation, development, and protection of the mark (Napoli, 2006).

Among the companies with clearly defined strategy, branding, dominated to a large extend (Berthon, Ewing, \& Napoli, 2008). A critical question that many SMEs often ask themselves is whether it is worthwhile spending a 
substantial amount of money, time, and energy in rethinking their marketing practices, adopting a strategic marketing approach (Noble, Sinha, \& Kumar, 2002) and going through the branding exercise. Though tempted to reorganize their marketing practices and adopt branding strategies, SMEs very often cannot do conventional marketing, because of the limitations of resources (Uüsitalo, Wendelin, \& Mahlamäki, 2010) and several other barriers. Such limitations can be summarized as: limited resources (such as finance (Ohnemus, 2009)), time and knowledge of marketing); lack of specialist expertise (owner-managers tend to be generalists rather than specialists); and limited impact in the marketplace (Gilmore et al., 2001).

Designing the differentiation and recognition a branding strategy is very important (Pringle \& Thompson, 1999). It makes a priority in designing an effective marketing mix (Wong \& Merrilees, 2005), and builds it gradually in line with the vision and strategy for meeting the needs and desires of customers (Mats, 1999). Branding is the process of transforming functional assets into relationship assets (Kim, Lavack, \& Smith, 2001). A well-crafted brand picture can guide company to develop right strategies (Davis, 2000).

Companies have to manage and protect their brands in their developments (Gillespie et al., 2007). Brands represent a link with consumers (Caprara, Barbanelli, \& Guido, 2001), consumers knowledge (Keller, 1993), and trust to ensure a quick and easy selection (Morris, 1996). Product (service) that has the credibility and helps customers to identify companies (Kumar, 2003), offer, and provide satisfaction with product (Knowles, 2001). Also co-branding with customers is becoming more common, as suppliers and customers recognize its potential advantages (Capon et al., 2001).

The main research questions of the article are therefore: (1) How is the brand managed in small or medium sized company within its different perspective on the market? and (2) What are the typical groups of companies (clusters)?

\section{Methodology and Sampling}

Consistent with prior literature survey, from which research questions were generated, we focused on SMEs. An empirical survey in 2010 was conducted using mail questionnaires. This measurement instrument was developed in two phases. Firstly, a preliminary research was conducted, qualitative study based on depth interviews were conducted with entrepreneurs in 10 different organizations.

Based on preliminary research, the questionnaire was finalized after several modifications of the layout and wording of questions. It was decided to omit one-man-bands from the sample. The sample was stratified to the range between six and 250 employees. The direct mail questionnaire was sent out to 2,500 businesses which were selected from the IPIS database using a random sampling technique.

Data were collected from entrepreneur or chief executive officer. We measured the respondents' views on five point Likert scale. In addition, we monitored SMEs: how they see importance of branding, its strategy development and management. Sixty questionnaires were returned to us unopened with 176 usable questionnaires retained for analysis. The standardized tools of statistical analysis such as cluster analysis we used for research questions exploration. Collected data were statistic analysed with SPSS software version 15.

\section{Results}

\section{Demographics Data}

Most of the respondents who responded to the questionnaire, belonged to our research target group of 
entrepreneurs/chief executive officers (82.5\%). Seventy-six percent of usable questionnaires were returned by male respondents, which confirms the proportion of male/female entrepreneurs in Slovenia, in fact, is rather small and lays behind the European average. The age of respondents was between 23 and 72 years old, $20 \%$ of them were aged under 40 years, $70 \%$ of them were between 40 and 60 years, and $10 \%$ of them were older than 60 years. Almost half (49\%) of respondents had technical backgrounds and one third the economics or business. Level of education was different: Forty-eight percent of respondents completed vocational or secondary school, while other graduated at college, university or even obtained post-graduate $(9.5 \%)$ education. Three quarters of respondents were without previous work experience abroad, the other majority had experience across the border, mostly in the succession countries of former Yugoslavia. Forty percent of them earned more than 1 million euros revenue in 2009 and $60 \%$ recorded less than 1 million euros. Half of the enterprises were employing up to 10 employees, the largest in the sample employed 80 people. More than $60 \%$ of respondents considered their business as a family business, $80 \%$ of them are still in the hands of founding generation.

\section{Results}

Before the establishment of the company, the future entrepreneur needs to develop a business idea, create a business plan, and decide on the name of the company. All of these activities can be done bearing the desired brand in mind to facilitate the future corporate brand building efforts. After the establishment of the company, all of the brand building activities identified in this study need to be conducted during the inception and survival stages.

Visual stimuli are critical part of any branding strategy. These stimuli include the logo, signage, packaging, product design, advertisements, and web sites. Hutton (1997) and some other authors argue that visual stimuli can assist in building strong brands by differentiating products, creating loyalty, allowing for premium pricing, cutting through clutter, and protecting against competition. In conjunction with this, we test whether and how Slovenian SMEs branded their company, who developed logo, type of relationships between designer and company, how much they invest to design and if they had registered and protected brand, $8.9 \%$ of the respondents said that they did not have any branding marks of their business, other respondents use logo, signage, packaging, product design, advertisements, and web sites, $39.4 \%$ of respondents think that they had good designed firm's identity, $30.6 \%$ have developed the logo and signage, $21.1 \%$ of them stated that they have formed signage. Their image was designed by amateur designer (9.4\%), a person from printing industry (8.3\%), an architect (3.9\%) or a marketing agency $(2.8 \%)$. The person who created the image was in most cases not related or associated with entrepreneurs (59.4\%), only $32.8 \%$ of respondents said that they were related. Mostly, they did not pay anything for their brand design (42.8\%) or they paid less than 2000 euros (40\%). Only 10.6\% of them paid more than 2000 euros for creating image, $63.9 \%$ of respondents do not legally protect their logo and only $23.9 \%$ of respondents registered and protected their logo, other respondents did not have any sign.

Researchers often encounter situations best resolved by defining groups of homogeneous individuals (Hair et al., 2010). Cluster analysis will always create clusters. The first task is developing some measuring instrument of similarity between each object. Next step is forming clusters on the similarity measure of each cluster. The resulting clusters should be of high internal homogeneity and high external heterogeneity. We used non-hierarchical clustering procedures also known as K-means cluster analysis which is a tool designed to assign cases to a fixed number of clusters whose characteristics are not yet known but are based on a set of specified variables. It is most useful when we want to classify a large number of cases. This procedure attempts to 
identify relatively homogeneous groups of cases based on selected characteristics, using an algorithm that can handle large numbers of cases. However, the algorithm requires you to specify the number of clusters. One can specify initial cluster centres if this information is known.

Preliminary results show that SMEs can be robustly classified into four different groups regarding their understanding of branding and related activities. The four groups can be partly contextualized within Porter's generic strategy framework and were identified in the study as: (1) In the start-up phase of life cycle, SMEs show almost no awareness of branding; (2) In early growth phase when they start to do some activities (logo development etc.); (3) In the phase of the need for a strategic orientation, their branding would depend on whether they aim for low-cost strategy (some formal branding activities); or (4) Their strategic orientation would be differentiation which is by definition expected to be built on powerful branding.

We select one from two methods for classifying cases, either updating cluster centres iteratively or classifying only. We save cluster membership, distance information, and final cluster centres. Optionally, we specify a variable whose values are used to label case wise output. We also request analysis of variance F-statistics. While these statistics are opportunistic (the procedure tries to form groups that do differ), the relative size of the statistics provides information about each variable's contribution to the separation of the groups. The analysis proceeded in a number of stages.

Distance from cluster centre creates a new variable indicating the Euclidean distance between each case and its classification centre. Clusters 1 and 4 are most different. Cluster 2 is similar to cluster 3 and different to cluster 4, and cluster 3 is similar to cluster 1 (see Table 1). The ANOVA indicates which variables contribute the most to cluster solution. Variables with large $F$-values provide the greatest separation between clusters (see Table 2). The final cluster centres reflect the characteristics of the typical case for each cluster. They are computed as the mean for each variable within each final cluster. According to the findings of the cluster analysis we estimate four final cluster centers (see Tables 3 and 4): ignorant (12\%), users (41\%), low costs producers $(39 \%)$, and differentiation producers $(8 \%)$. Some of them had passive, reactive, and proactive branding strategies (see Figure 1).

Table 1

Distances Between Final Cluster Centres

\begin{tabular}{|c|c|c|c|c|c|}
\hline Cluster & & 1 & 2 & 3 & 4 \\
\hline \multirow{4}{*}{ Dimension } & 1 & & 5.075 & 3.285 & 4.283 \\
\hline & 2 & 5.075 & & 4.659 & 8.182 \\
\hline & 3 & 3.285 & 4.659 & & 6.886 \\
\hline & 4 & 4.283 & 8.182 & 6.886 & \\
\hline
\end{tabular}

Table 2

ANOVA

\begin{tabular}{|c|c|c|c|c|c|c|}
\hline \multirow[b]{2}{*}{ Item } & \multicolumn{2}{|c|}{ Cluster } & \multicolumn{2}{|c|}{ Error } & \multirow[b]{2}{*}{$F$} & \multirow[b]{2}{*}{ Sig. } \\
\hline & $\begin{array}{l}\text { Mean } \\
\text { Square }\end{array}$ & $d f$ & $\begin{array}{l}\text { Mean } \\
\text { Square }\end{array}$ & $d f$ & & \\
\hline Customers trust on our products and services & 2.100 & 3 & 0.601 & 144 & 3.496 & 0.017 \\
\hline Brand name does not affect to the selling price & 7.835 & 3 & 1.574 & 144 & 4.979 & 0.003 \\
\hline $\begin{array}{l}\text { Attractive package is on of the most effective tools of the sales } \\
\text { performance }\end{array}$ & 10.976 & 3 & 1.282 & 144 & 8.564 & 0.000 \\
\hline Our customers trust to the name of our company & 5.557 & 3 & 0.833 & 144 & 6.675 & 0.000 \\
\hline
\end{tabular}


(Table 2 continued)

\begin{tabular}{|c|c|c|c|c|c|c|}
\hline \multirow[b]{2}{*}{ Item } & \multicolumn{2}{|c|}{ Cluster } & \multicolumn{2}{|c|}{ Error } & \multirow[b]{2}{*}{$F$} & \multirow[b]{2}{*}{ Sig. } \\
\hline & $\begin{array}{l}\text { Mean } \\
\text { Square }\end{array}$ & $d f$ & $\begin{array}{l}\text { Mean } \\
\text { Square }\end{array}$ & $d f$ & & \\
\hline $\begin{array}{l}\text { The form of our product or services do not significantly influence the } \\
\text { selling }\end{array}$ & 5.364 & 3 & 1.523 & 144 & 3.522 & 0.017 \\
\hline Our customers trust to the director of our company & 0.284 & 3 & 1.326 & 144 & 0.214 & 0.886 \\
\hline Low prices are most important for a good sale & 21.854 & 3 & 1.046 & 144 & 20.893 & 0.000 \\
\hline $\begin{array}{l}\text { The sales staff does not contribute significantly to our sales } \\
\text { performance }\end{array}$ & 4.100 & 3 & 1.406 & 144 & 2.916 & 0.036 \\
\hline The brand has a significant impact on sales volume & 11.183 & 3 & 0.878 & 144 & 12.732 & 0.000 \\
\hline Our customers trust to our brand name & 8.474 & 3 & 0.681 & 144 & 12.443 & 0.000 \\
\hline $\begin{array}{l}\text { The brand has a strong influence on the reputation of the company as a } \\
\text { whole }\end{array}$ & 17.287 & 3 & 0.626 & 144 & 27.626 & 0.000 \\
\hline The brand represents our major competitive advantage & 13.063 & 3 & 0.784 & 144 & 16.670 & 0.000 \\
\hline We use company logo on business cards, letters, e-mail, etc. & 4.223 & 3 & 0.723 & 144 & 5.842 & 0.001 \\
\hline The symbol of our company is our trademark & 27.405 & 3 & 0.805 & 144 & 34.030 & 0.000 \\
\hline We use company logo on product package & 40.603 & 3 & 1.232 & 144 & 32.948 & 0.000 \\
\hline Our brand is signed to buildings, shops, cars, etc. & 47.300 & 3 & 1.079 & 144 & 43.847 & 0.000 \\
\hline We use the symbol or brand name in advertisements. & 41.480 & 3 & 0.693 & 144 & 59.881 & 0.000 \\
\hline $\begin{array}{l}\text { The company name signed inside of business (offices, corridors, } \\
\text { manufacturing facilities, warehouses, etc.) }\end{array}$ & 36.636 & 3 & 1.367 & 144 & 26.808 & 0.000 \\
\hline The brand should be designed in function of the product/service & 8.024 & 3 & 0.977 & 144 & 8.215 & 0.000 \\
\hline $\begin{array}{l}\text { The brand should be designed so that the utmost account of the wishes } \\
\text { of the director. }\end{array}$ & 1.372 & 3 & 1.289 & 144 & 1.064 & 0.366 \\
\hline The brand should be designed according to customer expectations & 5.177 & 3 & 1.311 & 144 & 3.949 & 0.010 \\
\hline $\begin{array}{l}\text { Brands do not provide the primary points of differentiation to } \\
\text { competitive offer }\end{array}$ & 22.541 & 3 & 1.051 & 144 & 21.446 & 0.000 \\
\hline
\end{tabular}

Table 3

Final Cluster Centres

\begin{tabular}{|c|c|c|c|c|}
\hline \multirow{2}{*}{ Item } & \multicolumn{4}{|c|}{ Cluster } \\
\hline & 1 & 2 & 3 & 4 \\
\hline Customers trust to our products and services & 4 & 4 & 5 & 5 \\
\hline Brand name does not affect to the selling price & 3 & 4 & 2 & 3 \\
\hline Attractive package is one of the most effective tools of the sales performance & 2 & 4 & 3 & 2 \\
\hline Our customers trust to the name of our company & 4 & 4 & 4 & 3 \\
\hline The form of our product or services do not significantly influence the selling & 3 & 4 & 2 & 3 \\
\hline Our customers trust to the director of our company & 3 & 3 & 3 & 3 \\
\hline Low prices are most important for a good sale & 3 & 5 & 2 & 3 \\
\hline The sales staff does not contribute significantly to our sales performance & 2 & 2 & 2 & 2 \\
\hline The brand has a significant impact on sales volume & 3 & 5 & 4 & 3 \\
\hline Our customers trust to our brand name & 4 & 4 & 4 & 3 \\
\hline The brand has a strong influence on the reputation of the company as a whole & 3 & 5 & 5 & 3 \\
\hline The brand represents our major competitive advantage & 3 & 5 & 4 & 3 \\
\hline We use company logo on business cards, letters, e-mail, etc. & 4 & 4 & 5 & 4 \\
\hline The symbol of our company is our trademark & 4 & 5 & 5 & 2 \\
\hline We use company logo on product package & 3 & 5 & 4 & 2 \\
\hline Our brand is signed on buildings, shops, cars, etc. & 3 & 4 & 5 & 2 \\
\hline We use the symbol or brand name in advertisements & 4 & 5 & 5 & 2 \\
\hline $\begin{array}{l}\text { The company name signed inside of business (offices, corridors, manufacturing facilities, } \\
\text { warehouses, etc.) }\end{array}$ & 3 & 4 & 4 & 2 \\
\hline
\end{tabular}


(Table 3 continued)

\begin{tabular}{|c|c|c|c|c|}
\hline \multirow{2}{*}{ Item } & \multicolumn{4}{|c|}{ Cluster } \\
\hline & 1 & 2 & 3 & 4 \\
\hline The brand should be designed in function of the product/service & 4 & 4 & 4 & 3 \\
\hline The brand should be designed so that the utmost account of the wishes of the director & 3 & 3 & 2 & 2 \\
\hline The brand should be designed according to customer expectations & 4 & 4 & 4 & 3 \\
\hline Brands do not provide the primary points of differentiation between competitive offer & 2 & 5 & 2 & 3 \\
\hline
\end{tabular}

Table 4

Number of Cases in Each Cluster

\begin{tabular}{lllr}
\hline & 1 & 61 & $41 \%$ \\
Cluster & 2 & 11 & $8 \%$ \\
& 3 & 58 & $39 \%$ \\
& 4 & 18 & $12 \%$ \\
\hline Valid & & 148 & $100 \%$ \\
Missing & 32 & \\
\hline
\end{tabular}

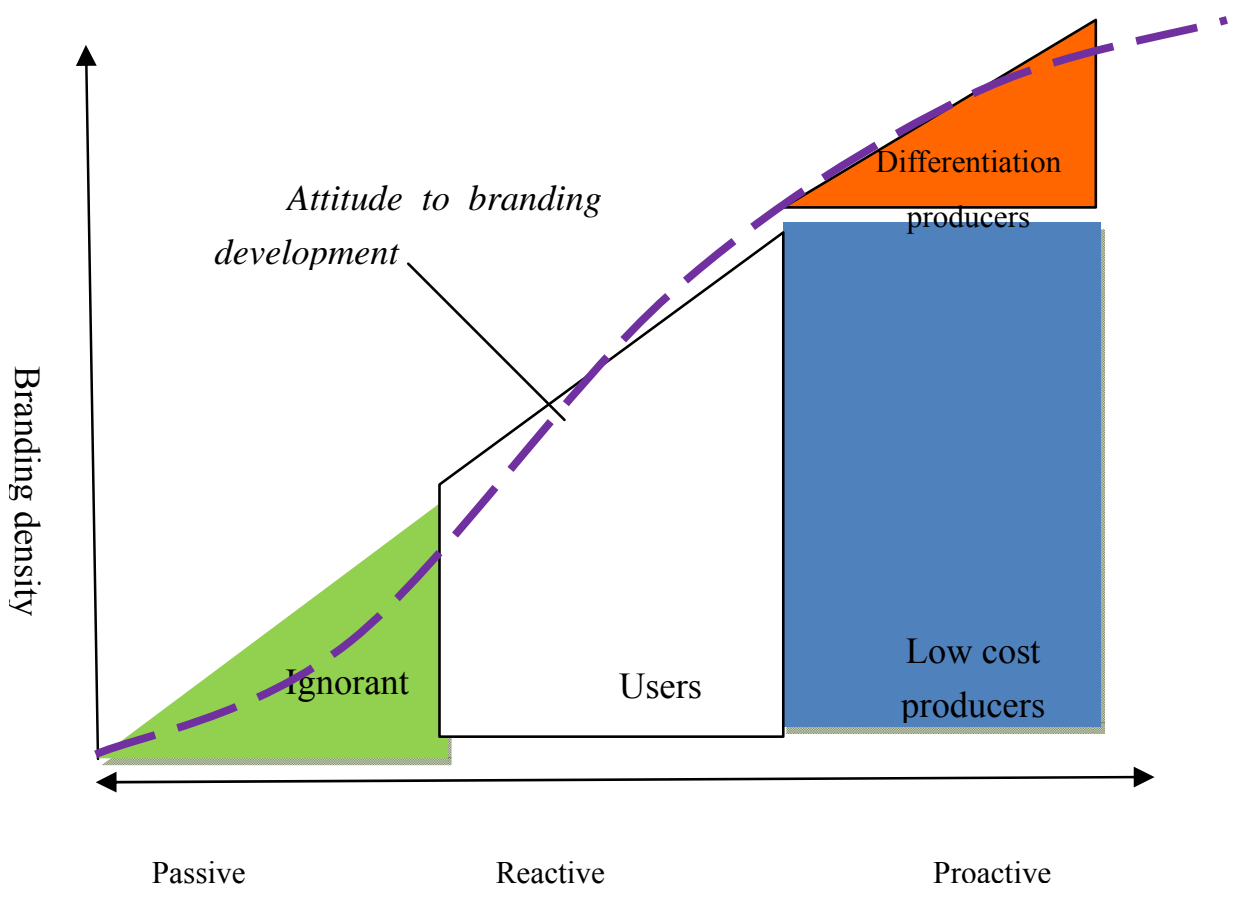

Figure 1. The role of branding of SMEs.

Ignorants (cluster 4) are passive they use some elements of branding: symbols, special characters printed on the business cards and official letters, but they not confer special interest to trademarks in their business. A large number of cases were assigned to the second cluster users (cluster 1) which use elements of branding printed on the business cards, official letters, e-mail advertisements. The symbol of a company is a trade mark and it is designed according to the customer expectations and customers' trust to brand. Ignorant and users cluster is more passive eventually reactive than strategic oriented. Businesses are usually locally oriented.

Low cost producers (cluster 3). They use brand visual stimuli, such as signs on printed materials, special 
designed buildings and offices, signed cars, etc.. Great importance in shaping the trade mark is attributed to the anticipation of customer and product functionality. Brand has not had a significant impact on selling success of the product or service. Low price is the most important tool for good sales. Differentiation producers (cluster 2) are very conscious of the importance of branding and want to improve their operations and process. Perhaps, the fourth group is most profitable. Customers trust to company's name, great importance in shaping is attributed to the anticipation of customer and product functionality. Company brand has a significant impact on sales volume, and effect to selling price, it provides the primary points of differentiation between offers of competitive firms.

Low cost and differentiation producers are proactive strategically oriented to branding, they operate to broader market. Branding is a strategic tool. It generally follows Porter's generic strategies of cost reduction and differentiation. Business strategy, marketing strategy, or promotion strategy must support brand strategy.

\section{Conclusions}

The results suggest that branding is not only a large companies' issue but SMEs could benefit from it as well, and they should be more carefully taken into account with small business companies (Ahonen, 2008). As marketing of SMEs differs from marketing of large companies, similarly branding issues of SMEs differ from branding issues of large companies. However, brand building can be done with smaller resources by being innovative, using affordable means of communication, and focusing the branding efforts on the right segments.

Study makes a significant contribution to the understanding of branding in the small business and entrepreneurial sectors in Slovenia. In other words, it clarified the current picture of branding, the views, and attitudes of entrepreneurs in SMEs to mark the importance of branding. Findings have important implications for SME managers. Study revealed that branding does exist among SMEs and interesting evidence about the positive consequences that firms with powerful branding policy may have: a higher attitude of those companies to business performances and customer relationships were revealed. Brand adds value and differentiation from competitors. Branding is an active and continuous process fed by innovations and product differentiation.

The first set of implications would be for assisting SMEs in the field of strategic orientation and marketing. This would also include different public support programs for SMEs which are usually broadly oriented and do not take into account the phase of development and maturity of SMEs. Findings from the research will contribute to better understanding of marketing to SMEs which may be included in the design and delivery of study courses at different levels.

Properly managed brands are essential to creating good business performance. It is important to take in mind that brands have long-term value, yet what may take many years to develop can be quickly lost through inappropriate managerial decisions (Capon et al., 2001). Branding is part of the marketing and strategic orientation processes.

The value of the study would be in broader understanding of the complexity of the SMEs' marketing and strategic orientation processes. This will be shifted away from often misleading common beliefs that marketing and branding activities are "for the big ones only".

\section{References}

Ahonen, M. (2008). Branding—Does it even exist among SMEs? Proceedings of the 16th Nordic Conference on Small Business Research. Tallinn, Estonia. 
Anarnkaporn, A. (2007). Branding as a competitive advantage for SMEs. RU. International Journal, 1(1), 25-36.

Berthon, P., Ewing, T. E., \& Napoli, J. (2008). Brand management in small to medium-sized enterprises. Journal of Small Business Management, 46(1), 27-45.

Capon, N., Berthon, P., James, M., Hulbert, J. M., \& Pitt, L. F. (2001). Brand custodianship: A new primer for senior managers. European Management Journal, 19, 215-227.

Caprara, G. V., Barbanelli, C., \& Guido, G. (2001). Brand personality: How to maske the mataphor fit? Journal of Economic Psyhology, 22(3), 377-395.

Chen, C. H. (2001). Using free associations to examine the relationship between the characteristics of brand associations and brand equity. Journal of Product \& Brand Management, 10(7), 439-451.

Courtney, H., Kirkland, J., \& Viguerie, P. (1997). Strategy under uncertainly. Harward Business Review, 75(6), 66-81.

Culkin, N., \& Smith, D. (2000). An emotional business: A guide to understanding the motivations of small business decision takers. Qualitative Market Research, 3(3), 145-157.

Davis, S. M. (2000). Brand asset management: Driving profitable growth through your brands. San Francisco, C.A.: Jossey-Bass Books.

Fournier, S., \& Lee, L. (2009). Getting brand communities right. Harvard Business Review, 87(4), 105-111.

Gillespie, K., Jeanett, J. P., \& Hennesy, H. D. (2007). Global marketing (2nd ed.). Boston, USA: Houghton Mifflin.

Gilmore, A. D., Carson, A., \& Grant, J. (2001). SME marketing in practice. Marketing Intelligence \& Planning, 19(1), 6-17.

Gilmore, A. D., Carson, A., \& O'Donnell, D. C. (1999). Added value: A qualitative assessment of SME marketing. Irish Marketing Review, 12(1), 27-35.

Goldberg, A. I., Coben, G., \& Fiegenbaum, A. (2003). Reputation building: Small business strategies for successful venture development. Journal of Small Business Management, 41(2), 168-186.

Grant, J. (2000). The new marketing manifesto: The 12 rules for bbuilding successful brands in 21 century. London: Orion Business Books.

Hair, J. F., Black, W. C., Babin, B. J., \& Anderson, R. E. (2010). Multivariate data analysis (7nd ed.). Upper Saddle River, N.Y.: Pearson-Prentice Hall Publisher.

Hutton, J. (1997). The influence of brand and corporate identity on consumer behavior: A conceptual framework. Journal of Brand Management, 5(3), 428-439.

Inskip, I. (2004). Corporate branding for small to medium-sized businesses - A missed opportunity or an indulgence? Brand Management, 11(5), 358-365.

Kahn, B., Kalwani, M., \& Morrison, D. (1988). Niching versus change-of-pace brands: Using purchase frequencies and penetration rates to infer brand positionings. Journal of Marketing Research, 25, 384-390.

Kapferer, J. N. (1997). Strategic brand management: Creating and sustaining brand equity long term (2nd ed.). London: Kogan Page Limited.

Keller, K. L. (1993). Conceptualizing, measuring, and managing customer-based brand equity. Journal of Marketing, 57(1), 1-22.

Kim, C. K., Lavack, A. M., \& Smith, M. (2001). Consumer evaluation of vertical brand extensions nand core brands. Journal of Business Research, 52(3), 211-222.

Knowles, J. (2001). The role of brand business. In J. Goodchild, \& C. Callow (Eds), Brands vision \& values. New York: John Willey \& Sons.

Kohli, C. S., Harich, K. R., \& Leuthesser, R. (2005). Creating brand identity: A study of evaluation of new brand names. Journal of Business Research, 58(11), 1506-1515.

Krake, F. B. (2005). Successful brand management in SMEs: A new theory and practical hints. Journal of Product and Brand Management, 14(4), 228-238.

Kumar, N. (2003). Kill a brand, keep a customer. Harvard Business Review, 81(11), 86-95.

Mats, U. (1999). Brand orientation: A mindset for building brands into strategic resources. Journal of Marketing Management, 15 (1-3), 117-133.

McAlester, J. (2006). The added value of niche brands: A theoretical and practical study of how niche branding adds value to the commercial offering of organisations and influences brand management. Retrieved from http://www.lulu.com/items/volume_34/535000/535239/1/print/535239.pdf

Merrilees, B. (2007). A theory of brand-led SME new venture development. Qualitative Market Research: An International Journal, 10(4), 403-415.

Morris, B. (1996). The brand's the thing. Fortune, 4(3), 72-76. 
Mowle, J., \& Merrilees, B. (2005). A functional and symbolic perspective to branding Australian SME wineries. Journal of Product \& Brand Management, 14(4), 220-227.

Napoli, E. (2006). Developing and validating a multidimensional nonprofit brand orientation scale. Journal of Business Research, 58(7), 841-853.

Nedeljković-Pravdić, M. (2010). How to create powerful brands-An investigation. Serbian Journal of Management, 5(1), 77-95.

Noble, C. H., Sinha, R. K., \& Kumar, A. (2002). Market orientation and alternative strategic orientations: A longitudinal assessment of performance implications. Journal of Marketing, 66(4), 25-39.

Ohnemus, L. (2009). B2B branding: A financial burden for shareholders? Business Horizonts, 52(2), 159-166.

Opoku, R. A., Abratt, R., Bendixen, M., \& Pitt, L. (2007). Communicating brand personality: Are the websites doing the talking for food SME's. Qualitative Market Research, 10(4), 362-374.

Pringle, H., \& Thompson, M. (1999). How cause related marketing builds brands. Satchi \& Satchi.

Ratnatunga, J., \& Ewing, M. T. (2009). An ex-ante approach to brand capability valuation. Journal of Business Research, 62(3), 323-331.

Slater, S. F., \& Narver, J. C. (2000). Intelligence generation and superior customer value. Journal of the Academy of Marketing Science, 28(1), 120-127.

Spence, M., \& Essoussi, L. H. (2010). SME brand building and management: An exploratory study. European Journal of Marketing, 44(7/8), 1037-1054.

Uüsitalo, O., Wendelin, R., \& Mahlamäki, T. (2010). Branding as an opportunity of SMEs' internationalization strategy in B2B market. Retrieved from http://www.impgroup.org/uploads/papers/7298.pdf

Wong, H. Y., \& Merrilees, B. (2005). A brand orientation typology for SMEs: A case research approach. Journal of Product \& Brand Management, 14(3), 155-162. 